\title{
Periodontal Diseases: A Covert Focus of Inflammation in Pulmonary Diseases
}

\author{
Abhaya Gupta, Umesh Pratap Verma, Ajay Kumar Verma'1, Shyam Chand Choudhary², Sakshi Sharma, Neetu Singh³, Disha Sharma \\ Department of Periodontology, Faculty of Dental Sciences, King George's Medical University, Departments of ${ }^{1}$ Pulmonary and Critical Care Medicine, \\ ${ }^{2}$ Medicine and ${ }^{3}$ Molecular Biology Center for Advanced Research, King George's Medical University, Lucknow, Uttar Pradesh, India
}

\section{Abstract}

Pulmonary diseases have known to exert significant human sufferings with high death toll globally. The association between periodontitis and pulmonary diseases is still in its infancy and needs attention. Poor oral health has shown to influence pulmonary health as well as the course of the diseases associated with this system. Numerous studies have emphasized that resident microorganisms of lungs are primarily the habitants of oral cavity. It could be due to the aspiration of oral periodontopathic bacteria into the lungs, thereby initiating the inflammatory process. Added to this, the inflammatory mediators elaborated from the inflamed periodontium in case of periodontal diseases may spread via blood to other organs such as lungs causing infections. Numerous studies have highlighted the beneficial role of periodontal therapy in improving lung function with a decreased frequency of exacerbations, reduced risk of adverse respiratory events, and morbidity, especially in chronic obstructive pulmonary disease patients. Medically compromised dentate patients admitted in intensive care units owing to their inability to maintain oral hygiene properly have increased propensity of acquiring respiratory infections. The present review focuses on emphasizing the relationship between periodontitis and pulmonary diseases with the available published literature utilizing PubMed and Google Scholar databases in the last four decades.

Keywords: Aspiration pneumonia, asthma, bronchiectasis, chronic obstructive pulmonary diseases, chronic periodontitis, tuberculosis

\section{INTRODUCTION}

A growing interest has emerged relative to the relationship between oral health and systemic diseases since the last few decades. ${ }^{[1,2]}$ Compelling evidence has highlighted the pivotal link between oral health and respiratory health due to the anatomical communication between the two. Pulmonary diseases have led to disability with high mortality rate and economic burden on the sufferers. It was estimated that the total mortality because of the lower respiratory infections remained roughly constant from 2005 to 2015 , i.e., between 2.7 million and 2.8 million deaths. ${ }^{[3]}$ Chronic respiratory diseases constitute around $4 \%$ of the global burden with overall burden of chronic diseases as $8.3 \%$. Recent accumulating evidence is suggestive of a high prevalence of allergic disorders, asthma, and chronic obstructive pulmonary disease (COPD) in the Asia-Pacific region. ${ }^{[4-7]}$ There are limited data on the respiratory disease burden in India, with recent reports showing prevalence ranging from $2.05 \%$ to $3.5 \%{ }^{[8,9]}$

The prime sufferers of community-acquired pneumonia are the ones that are affected by seizures, cerebral stroke, alcohol

\begin{tabular}{|l|l|}
\hline \multicolumn{2}{|c|}{ Access this article online } \\
\hline Quick Response Code: & Website: \\
\hline & www.ijrconline.org \\
\cline { 2 - 2 } & \\
\hline
\end{tabular}

abuse, etc. These conditions affect their cognitive ability, thereby increasing the chances of aspirating oropharyngeal secretions and hence respiratory infections. Smoking leads to compromised mucociliary barrier and phagocytic cell activity. Other predisposing factors causing immunological and physiological compromise include congenital derangements in immune-defense, acquired immunodeficiency, COPD, and hospitalized patients. It also leads to emergence of antibiotic-resistant pathogens in such patients and ultimately more susceptibility to pulmonary infections.

\section{Patients and Methods}

The present review discusses the studies utilizing the electronic databases PubMed and Google Scholar from 1977 to 2017

\section{Address for correspondence: Dr. Umesh Pratap Verma Department of Periodontology, Faculty of Dental Sciences, King George's Medical University, Lucknow, Uttar Pradesh, India. E-mail: umeshpratapverma@kgmcindia.edu}

This is an open access journal, and articles are distributed under the terms of the Creative Commons Attribution-NonCommercial-ShareAlike 4.0 License, which allows others to remix, tweak, and build upon the work non-commercially, as long as appropriate credit is given and the new creations are licensed under the identical terms.

For reprints contact: reprints@medknow.com

How to cite this article: Gupta A, Verma UP, Verma AK, Choudhary SC, Sharma S, Singh N, et al. Periodontal diseases: A covert focus of inflammation in pulmonary diseases. Indian J Respir Care 2019;8:8-17. 
using keywords "Aspiration pneumonia," "Asthma," "Chronic obstructive pulmonary diseases," "Chronic periodontitis," "Tuberculosis," and "Bronchiectasis" utilizing the Boolean operators "AND," "OR," and "NOT" in various combinations. The authors have utilized the five most common pulmonary diseases that are found to be associated with periodontal diseases on the basis of the published literature. A total of 76 scientific papers (33 observational studies, 16 interventional studies including 6 randomized controlled trials, 11 review articles including 1 systematic review and meta-analysis, and 16 in vitro studies) and 3 book reviews meeting the criteria were scrutinized for reviewing.

\section{Dental Plaque: The Repository of Pulmonary Pathogens}

Incredible increase in the quantity as well as complexity of dental biofilm was observed in hospitalized and critically ill patients because of their inadequate oral hygiene maintenance. ${ }^{[10-13]}$ The interaction between the resident dental plaque flora and established respiratory microbes ${ }^{[14]}$ ultimately leads to colonization by the latter in the niches of oral cavity. Consequently, dental plaque may shed into the salivary fluids due to a number of physiological forces contaminating the respiratory tree distally on aspiration [Figure 1].

The mechanisms explaining the prime role of periodontal bacteria in the etiopathogenesis of pulmonary infections have been proposed in the existing published literature. These are as follows: (1) aspiration of oral pathogens and specially of periodontal interest are Porphyromonas gingivalis, Actinobacillus actinomycetemcomitans, etc. ${ }^{[15-23]}$ [Figure 2], (2) modification of mucosal surface by periodontitis-associated salivary enzymes promoting adhesion and colonization by pulmonary pathogens ${ }^{[24-29]}$ [Figure 3], (3) enzymatic disintegration of salivary pellicle adsorbed on pathogenic bacteria ${ }^{[30,31]}$ [Figure 4], and (4) alteration of pulmonary epithelium by the cytokines that are elaborated in periodontitis promoting enhanced infection by respiratory pathogens $^{[32-35]}$ [Figure 5].

\section{Interrelation between Bacterial Pneumonia and Periodontal Disease}

Bacterial pneumonia, in brief, is a parenchymal infection of lungs caused by a wide spectrum of microorganisms, i.e., bacteria, parasites, viruses, and fungi. It can develop either as de novo or as a superimposed infection due to a primary viral infection. Broadly categorized as hospital acquired (nosocomial) and community acquired, these differ relative to the spectrum of etiological agents. Epidemiological studies on ten Asian countries including India have reported that hospital-acquired pneumonia (HAP) accounts for an incidence rate of 1-21 cases in every 1000 patients who are admitted to hospital. ${ }^{[36]}$ HAP is associated with a high morbidity and mortality with long patient stay and economic burden on the patient. Ventilated patients in intensive care units with more than $48 \mathrm{~h}$ of ventilation are at continual risk for acquiring ventilator-assisted pneumonia (VAP) because of their incapability for oropharyngeal secretion clearance.

The etiopathogenesis involved in adult bacterial pneumonia is through aspiration of oropharyngeal secretions loaded with pathogens into the lower respiratory tree. This leads to

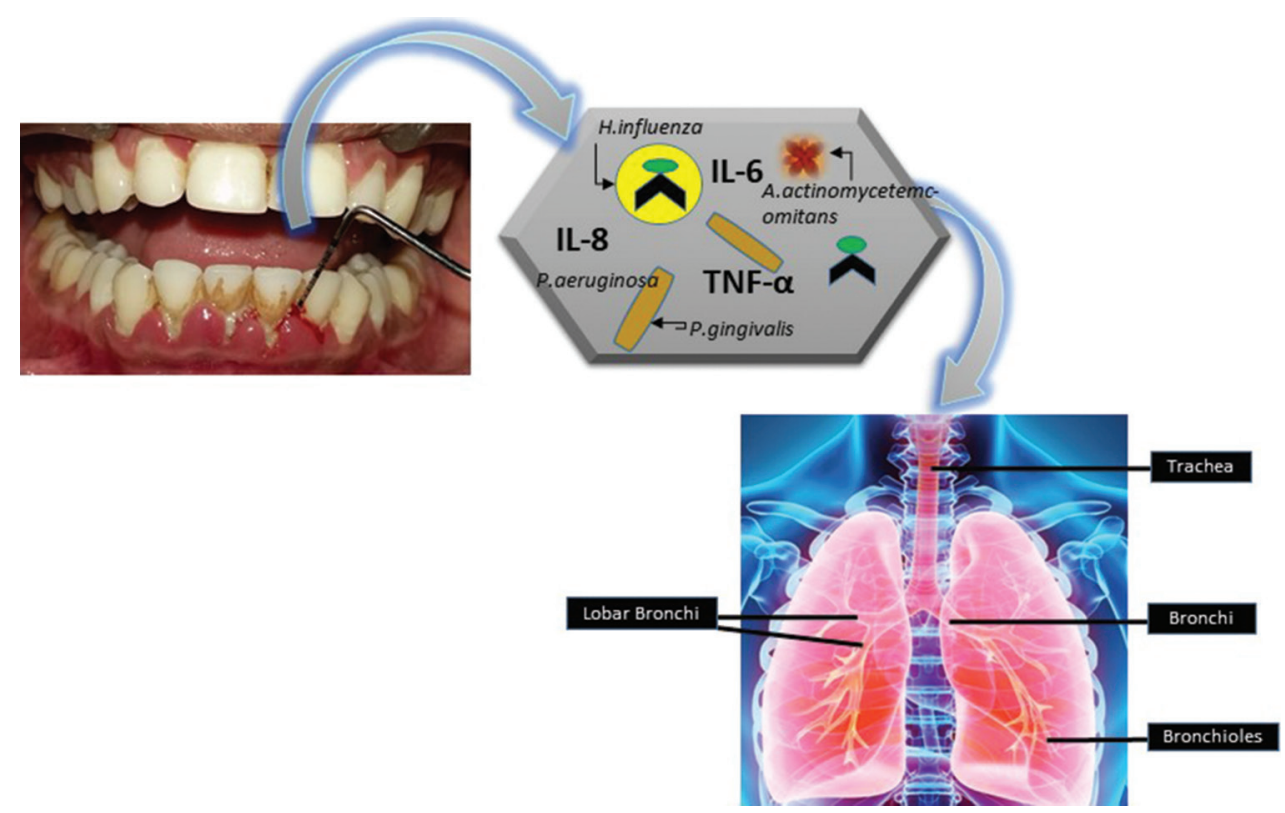

Figure 1: Link between periodontal bacteria and pulmonary infections. Due to the movement of the muscles of tongue and cheek during speech and mastication and by the flow of saliva, the dental plaque gets dislodged into saliva. It contains pathogenic bacteria associated with both periodontitis (Porphyromonas gingivalis, Actinobacillus actinomycetemcomitans, etc.) and pulmonary diseases (Pseudomonas aeruginosa, Klebsiella pneumonia, etc.). Salivary fluid containing inflammatory cytokines that seeps along with gingival crevicular fluid may initiate and progress pulmonary infection by stimulating a local inflammatory process 


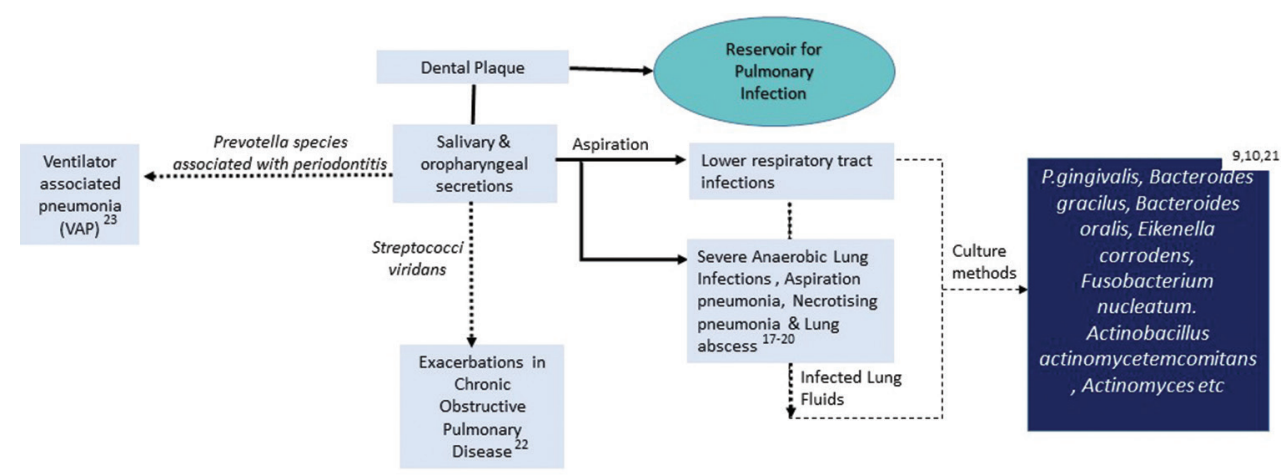

Figure 2: Possible mechanism of pulmonary infection via aspiration route

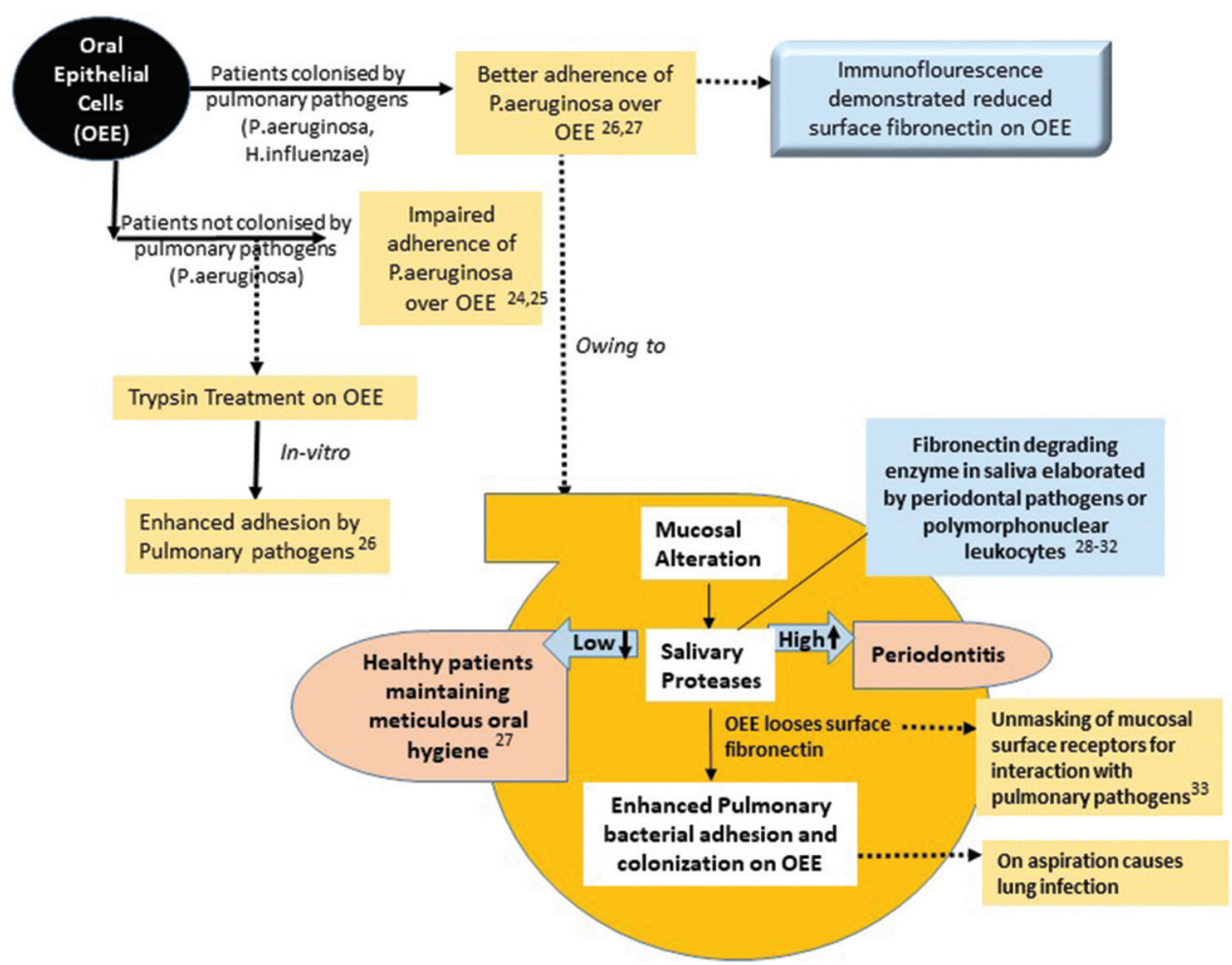

Figure 3: Possible mechanism of alteration of oral mucosal surfaces by periodontitis associated enzymes (proteases, sialidase, fucosidase, etc.,) resulting in adhesion and colonization pulmonary pathogens

collapse in host immune system responsible for eliminating the aspirated oral pathogens, which get a fair chance to multiply and flourish causing pulmonary infection. Since it is well established that pneumonia can be a resultant infection caused by anaerobic bacterial species, periodontitis patients carrying a large number of subgingival anaerobic bacteria can explain for a logical link between the two diseases. Perhaps infected lung fluids on culturing demonstrated various facultative and anaerobic microbial species of periodontal interest such as P. gingivalis, Bacteroides species, Fusobacterium nucleatum, and $A$. actinomycetemcomitans. ${ }^{[37,38]}$

It is well accepted that bacteria associated with an infectious process evoke a strong immunogenic response systemically. Antibody response to Prevotella species has been studied in periodontitis human subjects. A prospective study has also confirmed that patients suffering from VAP associated with Prevotella species elicit a strong systemic humoral response which seems to be specific to different species. Further, in the experimental group (patients who develop VAP associated with Prevotella species), the immunoglobulin M (IgM) titer was suggestive of a secondary immune response lacking $\operatorname{IgM}$, indicating that the patients may have had a previous periodontal infections with these bacteria. ${ }^{[23]}$ Therefore, it can be interpreted that colonization by Prevotella species in periodontitis patients may evoke a humoral immune response with consequent VAP.

Hence, in the elderly population, a correlation exists between dentition status and aspiration pneumonia. Numerous recommendations have been proposed to reduce the incidence of aspiration pneumonia in the form of either topical chemotherapeutic decontamination or mechanical oral hygiene 
Gupta, et al:: Association between periodontitis and respiratory disease

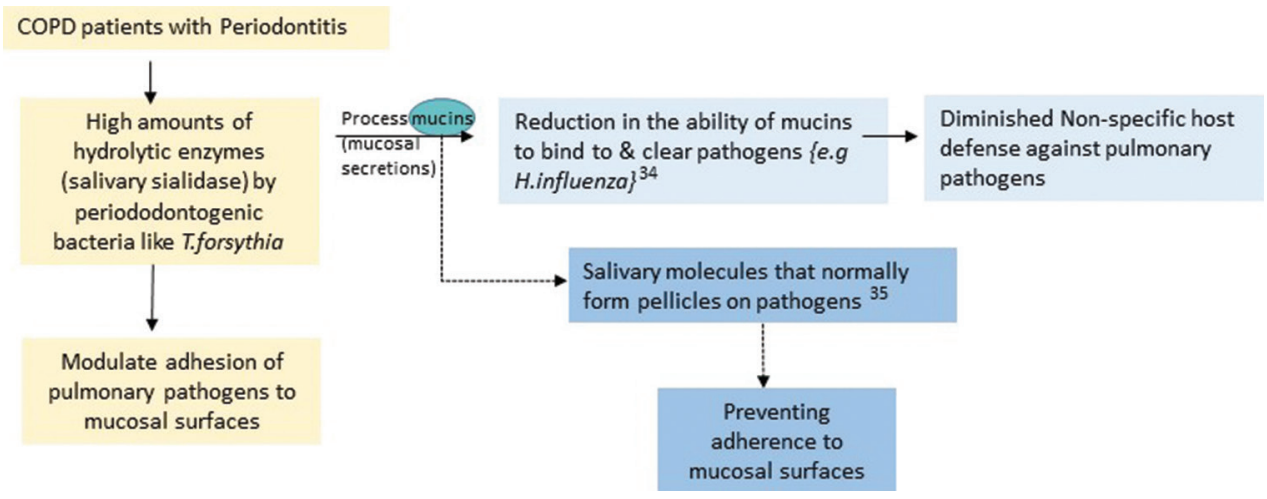

Figure 4: Mechanism explaining destruction of salivary pellicle by periodontal bacteria

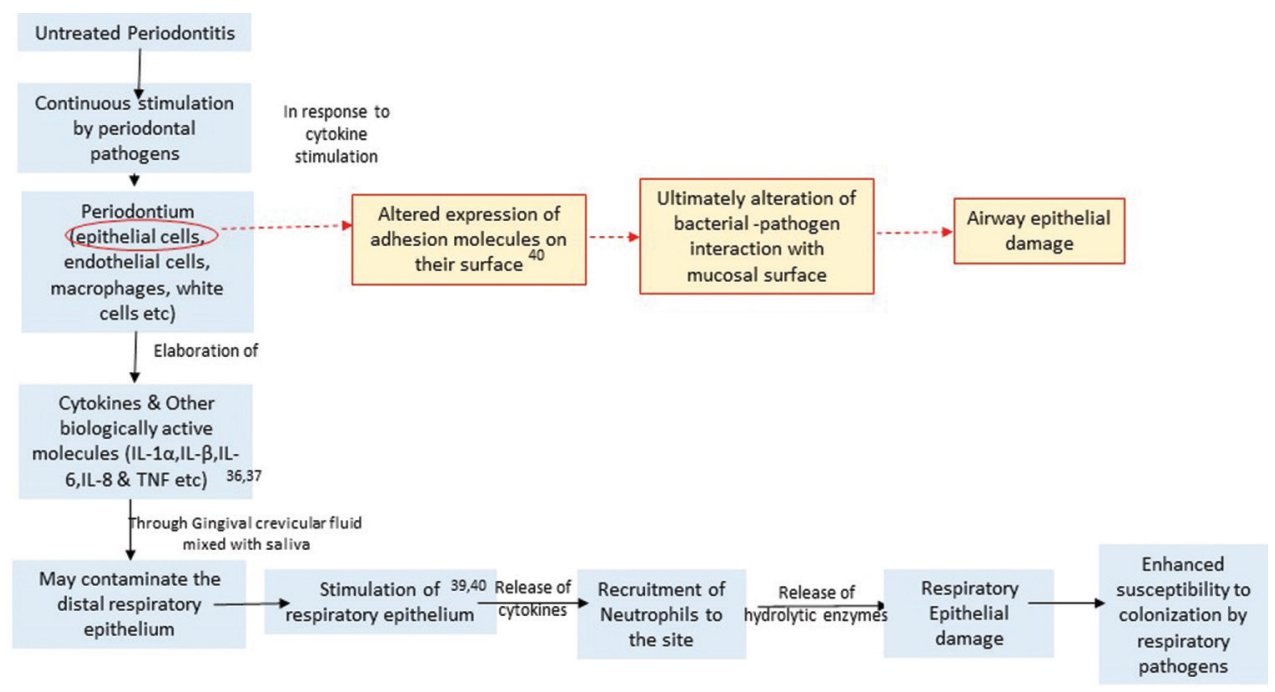

Figure 5: Mechanism explaining alteration of respiratory epithelium by salivary cytokines

maintenance by the professionals ${ }^{[10,24,39-47]}$ and are summarized in Table 1a.

\section{The Linkage between Chronic Obstructive Pulmonary Disease and Chronic Periodontitis}

COPD is an important global disease associated with quite a number of preventable risk factors. It is described as continuing obstruction to airflow that is progressive. It occurs as a result of exaggerated inflammatory response within airways and lungs that is chronic in nature. It is manifested in different variants such as emphysema, chronic bronchitis, and small airway disease.

Due to its heterogeneity and complexity, a set of standards has been defined by the Global Initiative for Chronic Obstructive Lung Disease (GOLD) in 1998 for accurate assessment and treatment of COPD. However, since COPD is not solely dependent on pulmonary function status but also dependent on the symptom burden and exacerbation frequency, the GOLD severity classification underwent a revision in 2011 to add assessment of symptom burden as well either by COPD assessment test ${ }^{[48]}$ or Modified British Medical Research Council scale ${ }^{[49]}$ with accompanying exacerbation history and accordingly grading into Groups A-D. In a recent update in GOLD classification, 2017, the risk profiling grading of the patients into A-D was based totally on symptom burden and history of exacerbation. Further spirometry readings were used to grade the patients from 1 to 4 on the basis of airflow limitation.

The role of periodontal disease as a risk factor for COPD has received exponential interest of the researchers over the last two decades due to the possibility of aspirating periodontal pathogens since oral cavity and lungs harbor anatomical communication. Furthermore, acute exacerbations are prevalent in COPD patients, majority of which remain unreported and deteriorate quality of life. Microaspiration occurs in healthy situations, but the local defense (mechanical and immunological) mechanism provides protection to the distal airways and parenchyma of lungs. However, in pulmonary disease patients with poor oral hygiene and periodontitis, the bacteria-laden oral secretions may not be cleared off, resulting in respiratory airway colonization and inflammation. ${ }^{[50]}$ Another possibility could be an acute phase reaction systemically due to the elaboration of biological mediators into circulation from the periodontally inflamed tissue. Although many epidemiological studies 
Gupta, et al.: Association between periodontitis and respiratory disease

\begin{tabular}{|c|c|c|c|}
\hline Author & Type of study & Years & Conclusion \\
\hline Scannapieco et al..$^{[10]}$ & $\begin{array}{l}\text { Prospective } \\
\text { Observational study }\end{array}$ & 1992 & $\begin{array}{l}\text { In medical ICU patients, dental plaque and oral mucosa can be a potential reservoir of } \\
\text { bacteria causing nosocomial pneumonia, and oral hygiene maintenance can reduce not } \\
\text { only dental plaque load but also oropharyngeal colonization }\end{array}$ \\
\hline Langmore et al..$^{[24]}$ & $\begin{array}{l}\text { Prospective outcome } \\
\text { study }\end{array}$ & 1998 & $\begin{array}{l}\text { Predictive risk factor such as oral/dental status was identified as a contributor to the } \\
\text { pathogenesis of aspiration pneumonia }\end{array}$ \\
\hline Fourrier et al. ${ }^{[39]}$ & $\begin{array}{l}\text { Prospective } \\
\text { Observational study }\end{array}$ & $\begin{array}{l}\text { September } \\
2000\end{array}$ & $\begin{array}{l}\text { Colonization of dental plaque by aerobic pathogens might be a source of nosocomial } \\
\text { infection (pneumonia and bacteremia) in ICU patients }\end{array}$ \\
\hline Genuit et al..$^{[40]}$ & Prospective study & 2001 & $\begin{array}{l}\text { Improved oral hygiene via topical CHX application in conjunction with the use of } \\
\text { a ventilator weaning protocol is effective in reducing the incidence of VAP and the } \\
\text { duration of mechanical ventilation in surgical ICU patients }\end{array}$ \\
\hline Adachi et al..$^{[41]}$ & Observational Study & $\begin{array}{l}\text { August } \\
2002\end{array}$ & $\begin{array}{l}\text { Professional oral health care in elderly patients requiring daily nursing care was related } \\
\text { with reduced prevalence in fatal pneumonia }\end{array}$ \\
\hline Koeman et al. ${ }^{[42]}$ & $\begin{array}{l}\text { Randomized, } \\
\text { double-blind, } \\
\text { placebo control trial }\end{array}$ & 2006 & Oral decontamination with topical $\mathrm{CHX}$ or $\mathrm{CHX} / \mathrm{COL}$ reduces the incidence of VAP \\
\hline Awano et al..$^{[43]}$ & Longitudinal study & $\begin{array}{l}\text { April } \\
2008\end{array}$ & $\begin{array}{l}\text { Mortality as a result of pneumonia was } 3.9 \text { times higher in persons with } 10 \text { or more } \\
\text { teeth with a probing depth exceeding } 4 \mathrm{~mm} \text { than in those without periodontal pockets }\end{array}$ \\
\hline Ishikawa et al. ${ }^{[44]}$ & Interventional study & June 2008 & $\begin{array}{l}\text { In dependent elderly individuals, professional mechanical cleaning of the oral cavity } \\
\text { on weekly basis, rather than a daily chemical oral disinfection, can prove to be an } \\
\text { important strategic consideration to avoid aspiration pneumonia }\end{array}$ \\
\hline Munro et al. ${ }^{[45]}$ & $\begin{array}{l}\text { Randomized } \\
\text { controlled clinical } \\
\text { trial }\end{array}$ & $\begin{array}{l}\text { September } \\
2009\end{array}$ & $\begin{array}{l}\text { CHX, but not toothbrushing, reduced early VAP in critically ill patients without } \\
\text { pneumonia at baseline }\end{array}$ \\
\hline Iinuma et al. ${ }^{[46]}$ & $\begin{array}{l}\text { Prospective } \\
\text { observational study }\end{array}$ & $\begin{array}{l}\text { March } \\
2015\end{array}$ & $\begin{array}{l}\text { In edentulous denture wearing patients, there is increased risk for acquiring pneumonia, } \\
\text { suggesting the role of denture-associated biofilm acting as a reservoir for pulmonary } \\
\text { infection }\end{array}$ \\
\hline Juthani-Mehta et al. ${ }^{[47]}$ & $\begin{array}{l}\text { Randomized } \\
\text { controlled trial }\end{array}$ & $\begin{array}{l}\text { March } \\
2015\end{array}$ & $\begin{array}{l}\text { Institution of manual oral brushing plus } 0.12 \% \mathrm{CHX} \text { oral rinse, twice daily, plus upright } \\
\text { positioning during feeding, reduces the incidence pneumonia in nursing home elderly } \\
\text { patients }\end{array}$ \\
\hline
\end{tabular}

VAP: Ventilator-assisted pneumonia, ICU: Intensive care unit, CHX: Chlorhexidine, COL: Colistin

have been conducted with positive results on association between periodontitis and risk of COPD,,$^{[50-54,63-69]}$ owing to the heterogeneity in utilization of measuring parameters and target population, the association showed variable results.

Briefly, both the diseases have similarity in the risk factors as well as the mechanisms behind their pathophysiology. Both are characterized by chronic inflammation with heavy infiltration by neutrophils and consequent loss of connective tissue due to proteolytic activity. This implicates that diagnosing and treating one disease properly would have a direct effect on the other diseases in terms of reduction in severity and/or disease progression. Studies highlighting the role of respiratory disease on oral health status along with the impact of periodontal attachment loss on the risk of occurrence of COPD and periodontal treatment in reducing exacerbations are summarized in Table $1 b$.

\section{Association between Asthma and Chronic Periodontitis}

Asthma is a chronic disease of airways, which get narrowed down either temporarily or permanently bringing about breathing difficulty. Although it occurs in people of all ages, the peak prevalence is seen between 6 and 11 years. It is characterized by recurrent episodic attacks of coughing, wheezing, and dyspnea.
The prevalence of asthma has been reported with alarming rise throughout the world. The most important etiological agent for asthma is mainly a Type E antibody-mediated allergic hypersensitivity reaction. This is characterized by the recruitment of the mast cells with the resultant elaboration of chemical mediators such as histamine. A similar kind of cellular picture is noticed in cases of gingivitis that give direction toward a similarity at immunological level between allergic reactions and periodontal diseases. ${ }^{[5]}$ The risk factors in asthma include genetics, host-derived factors, and environmental factors.

Although the initial studies finding an association between periodontitis and asthma were conducted in the 1970s, they showed inconclusive results. ${ }^{[57]}$ Further, only a small number of studies till date have highlighted the link between periodontal diseases and asthma, including other similar kind of respiratory allergies. ${ }^{[56-62,70-73]}$ A casual association has been proposed between the two diseases. This could be due to either the aspiration of oropharyngeal secretions laden with periodontal pathogens or spread of biochemical mediators from the inflamed periodontium via blood to distant organs such as lungs. Thus, poor oral hygiene can lead to worsening of pulmonary functions with increase in a number of exacerbations of asthmatic attacks. Proper management of periodontitis can benefit such asthmatic patients. 
Gupta, et al.: Association between periodontitis and respiratory disease

\begin{tabular}{|c|c|c|c|}
\hline Author & Type of study & Years & Conclusion \\
\hline Scannapieco et al. ${ }^{[51]}$ & Case-control study & July 1998 & $\begin{array}{l}\text { Significant associations between respiratory diseases (acute pneumonia, } \\
\text { emphysema, and chronic bronchitis) and oral health in community-dwelling } \\
\text { populations were seen }\end{array}$ \\
\hline Hayes et al. ${ }^{[63]}$ & $\begin{array}{l}\text { Longitudinal } \\
\text { observational study }\end{array}$ & July 1998 & $\begin{array}{l}\text { Increased radiographic alveolar bone loss was associated with an increased risk } \\
\text { of COPD }\end{array}$ \\
\hline Scannapieco and $\mathrm{Ho}^{[64]}$ & $\begin{array}{l}\text { Cross-sectional } \\
\text { retrospective study }\end{array}$ & January 2001 & $\begin{array}{l}\text { COPD patients had more periodontal attachment loss than individuals without } \\
\text { COPD. Individuals with mean periodontal attachment loss equal or more than } 3 \\
\text { mm had a higher risk of COPD than with lower values }\end{array}$ \\
\hline Hyman and Reid ${ }^{[65]}$ & Observational study & 2004 & $\begin{array}{l}\text { Smoking might act as a cofactor in the association between periodontal disease } \\
\text { and chronic obstructive pulmonary disease }\end{array}$ \\
\hline Kowalski et al..$^{[6]]}$ & Observational study & October 2005 & $\begin{array}{l}\text { Increased frequency and intensification of periodontal disease in COPD was } \\
\text { found }\end{array}$ \\
\hline Katancik et al..$^{[67]}$ & $\begin{array}{l}\text { Cross-sectional } \\
\text { study }\end{array}$ & November 2005 & $\begin{array}{l}\text { Does not reveal any significant association between periodontal disease and } \\
\text { airway obstruction, particularly in former smokers }\end{array}$ \\
\hline Leuckfeld et al..$^{[68]}$ & $\begin{array}{l}\text { Cross-sectional } \\
\text { retrospective study }\end{array}$ & April 2008 & $\begin{array}{l}\text { Demonstrated that chronic marginal periodontitis to be common in patients with } \\
\text { severe COPD and its high prevalence was found to be an independent possible } \\
\text { risk factor }\end{array}$ \\
\hline Deo et al..$^{[69]}$ & Retrospective study & $\begin{array}{l}\text { October-December } \\
2009\end{array}$ & $\begin{array}{l}\text { Severity in periodontal attachment loss was linked with increased risk of having } \\
\text { COPD }\end{array}$ \\
\hline Prasanna $^{[50]}$ & Observational study & October 2011 & $\begin{array}{l}\text { Association between periodontal disease and COPD with periodontitis as one of } \\
\text { the risk factors }\end{array}$ \\
\hline Si et al..$^{[52]}$ & Case-control study & 2012 & $\begin{array}{l}\text { A strong association was found between periodontitis and COPD with plaque } \\
\text { index to be a major predictor among Chinese adults }\end{array}$ \\
\hline Kucukcoskun et al. ${ }^{[53]}$ & $\begin{array}{l}\text { Prospective, } \\
\text { controlled group } \\
\text { trial }\end{array}$ & July 2013 & $\begin{array}{l}\text { significant reduction was found in exacerbation frequency in COPD patients } \\
\text { with chronic periodontitis who received periodontal therapy }\end{array}$ \\
\hline Zhou et al.$^{[54]}$ & Pilot RCT & April 2014 & $\begin{array}{l}\text { Both scaling and root planing and supragingival scaling improved periodontal } \\
\text { indices and lung function and reduced the frequency of chronic obstructive } \\
\text { pulmonary disease exacerbations }\end{array}$ \\
\hline
\end{tabular}

COPD: Chronic obstructive pulmonary disease

Apart from the direct effect that periodontal diseases have on asthmatic patients, there is reciprocal association also, i.e., the inhalers bring about change not only in $\mathrm{pH}$ but also a consequent reduction in salivary formation. This results in more dental plaque formation, thereby increasing the severity of periodontal disease. Further, corticosteroids that are utilized in asthmatic patients are immunosuppressive and cause reduced host immune response with resultant deceased expression of periodontal disease clinically.

The literature available throws light on the possible link between asthma and periodontal disease [Table 1c]. Added to this, there are secondary factors such as medications affecting the association. Due to the paucity of studies, the need of the hour is more number of longitudinal studies with greater sample size. This would lead to a better assessment of the possible association between the two diseases, so that the mechanisms behind their etiopathogenesis can be explored well along with their treatment more efficiently.

\section{Relation between Tuberculosis and Chronic Periodontitis}

Tuberculosis (TB) is considered to be one of the major debilitating diseases in most developing countries like India. It is a chronic granulomatous disease that primarily affects lungs although it can affect extrapulmonary sites such as skin, bones, lymph nodes, kidney, and oral cavity. According to the WHO report (2017), TB is the ninth leading cause of mortality worldwide with India alone accounting for $33 \%$ of TB deaths globally among HIV-negative people and $26 \%$ of the altogether total TB deaths in HIV-negative and HIV-positive people.

The treatment of TB involving highly efficacious chemotherapeutic agents has led to the occurrence of $<1 \%$ of tuberculous lesions in oral cavity. Primary lesions are rare, affecting younger adults with propensity toward gingival tissues. The cause of this rarity might be due to the presence of intact and thick squamous epithelium and protective role of saliva. On the contrary, secondary lesions affect older adults accounting for around $0.005 \%-1.5 \%$ of all cases.

Accumulating evidence has regarded TB as a predisposing or contributing factor in the pathogenesis of periodontal disease. Orofacial TB is not easy to diagnose and TB bacilli present in oral cavity may spread easily via saliva during expectoration. Since TB bacilli can survive in environment of low oxygen tension, periodontal pocket may act as a favorable site for colonization of this bacteria. There are numerous studies showing involvement of gingiva in systemic TB. A microbiological study utilizing the nested polymerase chain reaction in TB patients with periodontitis detected Mycobacterium TB in both plaque (92\%) and saliva $(68 \%)$ samples. This might be a possible risk of 
Gupta, et al.: Association between periodontitis and respiratory disease

\begin{tabular}{|c|c|c|c|}
\hline Author & Type of study & Years & Conclusion \\
\hline Hyyppä et al..$^{[57]}$ & Observational study & 1979 & Gingival inflammation gets increased in asthmatic patients \\
\hline Laurikainen K, Kuusisto $\mathrm{P}^{[64,80]}$ & $\begin{array}{l}\text { Observational study } \\
\text { (case-control) }\end{array}$ & March 1998 & $\begin{array}{l}\text { Periodontal status index in asthmatics was comparatively higher than } \\
\text { nonasthmatic individuals }\end{array}$ \\
\hline Shulman et al..$^{[58]}$ & $\begin{array}{l}\text { Cross-sectional } \\
\text { study }\end{array}$ & May 2003 & $\begin{array}{l}\text { No association was seen between asthma and periodontal health in an adolescent } \\
\text { population }\end{array}$ \\
\hline Friedrich et al. ${ }^{[59]}$ & Observational study & April 2006 & $\begin{array}{l}\text { Slightly inverse association was found between asthma-like respiratory allergies } \\
\text { and periodontitis }\end{array}$ \\
\hline Yaghobee et al. ${ }^{[60]}$ & Case-control study & 2008 & $\begin{array}{l}\text { Periodontal indices (papillary bleeding index and gingival index) and attachment } \\
\text { loss were higher among asthmatics }\end{array}$ \\
\hline Gomes-Filho et al. ${ }^{[61]}$ & Case-control study & June 2014 & $\begin{array}{l}\text { Higher frequency of periodontitis in individuals with severe asthma than in those } \\
\text { without a diagnosis of bronchial inflammation }\end{array}$ \\
\hline Rivera et al. ${ }^{[62]}$ & Longitudinal study & July 2016 & $\begin{array}{l}\text { Stronger evidence of an inverse association was seen when using asthma } \\
\text { medication as outcome in patients with severe periodontitis, i.e., less likely to } \\
\text { have asthma }\end{array}$ \\
\hline Lee et al. ${ }^{[70]}$ & $\begin{array}{l}\text { Cross-sectional } \\
\text { study }\end{array}$ & June 2017 & $\begin{array}{l}\text { Positive association between periodontitis and current asthma condition. } \\
\text { Individuals taking scheduled antiasthmatic medications are less likely to be } \\
\text { diagnosed with periodontitis }\end{array}$ \\
\hline Shen et al. ${ }^{[71]}$ & $\begin{array}{l}\text { Retrospective } \\
\text { Cohort study }\end{array}$ & August 2017 & Asthmatic patients are at elevated risk of developing periodontal diseases \\
\hline Soledade-Marques et al..$^{[72]}$ & Case-control study & April 2018 & $\begin{array}{l}\text { Frequency of asthma in individuals with periodontitis had about a three-fold } \\
\text { increased risk than that of those without asthma }\end{array}$ \\
\hline Moraschini et al. ${ }^{[73]}$ & $\begin{array}{l}\text { Systematic review } \\
\text { and meta-analysis }\end{array}$ & April 2018 & Strongly suggests association of asthma with periodontal disease \\
\hline
\end{tabular}

transmitting the bacteria via aerosols during dental treatment. A clinicomorphological study in periodontitis patients with pulmonary TB demonstrated small-to-middle-sized peridental foci of infection, suggesting immune or minor tuberculous inflammation with reparative processes. ${ }^{[74]}$

Studies highlighting the impact of pulmonary TB on periodontium are incorporated in Table 1d.

\section{Putative Association between Bronchiectasis and Chronic Periodontitis}

Bronchiectasis (Bronckos - airway; ectasia - dilatation) is described as abnormal, irreversible dilatation with thickened walls of bronchi. The abnormality seen in this disease primarily affects medium-sized bronchi, but can involve distal bronchi and bronchioles. It is clinically manifested with chronic cough and large amounts of mucopurulent expectoration. The possible etiology can be prior pulmonary infection, genetic predisposition with disorders affecting immunity, and idiopathic nature affecting up to approximately half of the individuals. According to an epidemiological survey analysis, 2012, there has been the highest prevalence of bronchiectasis cases that has been noticed in the Asia-Pacific countries.

Since both chronic periodontitis and bronchiectasis are chronic inflammatory diseases involving host-immune system, it might be possible that these diseases are linked as far as pathophysiology is concerned. Only two study protocols internationally have been proposed at present aiming at finding an association between the two diseases: one aiming at evaluating the improvement in pulmonary function, quality of life, and number of pulmonary exacerbations ${ }^{[78]}$ and other assessing the microbial load in saliva, sputum, and nasal lavage after periodontal treatment. ${ }^{[79]}$ At national level, no such study is documented. Due to the paucity of literature, it can be hoped that since COPD that bears clinical similarity with bronchiectasis, there might be possible linkage between the two at the level of signaling mechanisms involved in inflammatory pathways [Table 1e].

\section{Conclusion}

Poor periodontal health in patients with pulmonary disease is of prime concern owing to the possibility of aspirating periodontal microbes into lungs and the presence of defective respiratory defensive system in these patients. This increases the chances of colonization and multiplication of periodontal pathogens in respiratory pathways and initiating a local inflammatory reaction by altering the quality of respiratory epithelium at that site. Furthermore, this alteration can be attributed to the presence of periodontitis-associated cytokines and hydrolytic enzymes present in oropharyngeal secretions. Further, the biological mediators released from the inflamed periodontal tissues might reach distant organs such as lungs and cause pulmonary inflammation. Other mechanisms attempting to explain the role of periodontal bacteria in causing respiratory diseases can be the destruction of salivary pellicle on pathogenic bacteria by periodontitis-associated enzymes preventing their clearance from the mucosal surfaces.

Thus, poor oral health makes the patients suffering from pulmonary diseases (such as pneumonia, COPD, TB, and bronchiectasis) more susceptible to exacerbations and disease progression, especially hospitalized patients. There is epidemiologic evidence, suggesting that improved periodontal 
Gupta, et al.: Association between periodontitis and respiratory disease

\begin{tabular}{|c|c|c|c|}
\hline Author & Type of study & Years & Conclusion \\
\hline Avdonina et al. ${ }^{[74]}$ & $\begin{array}{l}\text { Observational } \\
\text { study }\end{array}$ & 1993 & $\begin{array}{l}\text { Persistent L-forms of } M \text {. tuberculosis (59.3\%) brought out a symptomless } \\
\text { periodontitis with small- and middle-sized PFI, manifest immune or minor } \\
\text { tuberculous inflammation, reparative processes. The findings suggest that PFI in } \\
\text { tuberculous patients' periodontitis is a form of extrapulmonary TB }\end{array}$ \\
\hline Anjum et al. ${ }^{[75]}$ & $\begin{array}{l}\text { Cross-sectional } \\
\text { observational study }\end{array}$ & November 2010 & No relationship between duration of illness and the periodontal status in TB patients \\
\hline Palakuru et al..$^{[76]}$ & In vitro study & $\begin{array}{l}\text { November-December } \\
2012\end{array}$ & $\begin{array}{l}\text { TB status had no influence on the periodontal status. However, the presence of } \\
\text { M. tuberculosis in saliva and dental plaque might pose a risk of transmission of } \\
\text { disease through aerosols during dental procedures }\end{array}$ \\
\hline Sharma et al. ${ }^{[77]}$ & Case-control study & October 2016 & $\begin{array}{l}\text { Increased probing depth and bleeding on probing was found to be associated with } \\
\text { TB patients than non-TB patients, concluding that periodontal status might be linked } \\
\text { with TB }\end{array}$ \\
\hline
\end{tabular}

TB: Tuberculosis, M. tuberculosis: Mycobacterium tuberculosis, PFI: Peridental foci of infection

\begin{tabular}{llll}
\hline \multicolumn{4}{l}{ Table 1e: Bronchiectasis versus chronic periodontitis } \\
\hline Author & Type of study & Years & Conclusion \\
\hline Pinto et al. ${ }^{[79]}$ & $\begin{array}{l}\text { Randomized controlled } \\
\text { trial protocol }\end{array}$ & 2016 & Under progress \\
Santos SR et al. ${ }^{[78]}$ & $\begin{array}{l}\text { Randomized controlled } \\
\text { trial protocol }\end{array}$ & 2017 & Under progress \\
\hline
\end{tabular}

health by proper dental management can reduce the number of pulmonary exacerbations and improve pulmonary functions and quality of life of patients. Further longitudinal studies with large sample size are needed to explore the putative association between periodontal disease and pulmonary diseases and to unravel the similar mechanisms involved in their pathogenesis not only at molecular level but also at genetic level. The novel genes should be identified which shows similar kind of differential expression in both these diseases that can be later on be targeted for diagnostic, prognostic, and therapeutic purposes.

\section{Financial support and sponsorship}

Nil.

\section{Conflicts of interest}

There are no conflicts of interest.

\section{REFERENCES}

1. Scannapieco FA. Position paper of the American Academy of Periodontology: Periodontal disease as a potential risk factor for systemic diseases. J Periodontol 1998;69:841-50.

2. Stamm JW. Periodontal diseases and human health: New directions in periodontal medicine. Ann Periodontol 1998;3:1-2.

3. Ng M, Fleming T, Robinson M, Thomson B, Graetz N, Margono C, et al. Global, regional, and national prevalence of overweight and obesity in children and adults during 1980-2013: A systematic analysis for the global burden of disease study 2013. Lancet 2014;384:766-81.

4. Wong GW, Leung TF, Ko FW. Changing prevalence of allergic diseases in the Asia-pacific region. Allergy Asthma Immunol Res 2013;5:251-7.

5. Wouters EF. Economic analysis of the confronting COPD survey: An overview of results. Respir Med 2003;97 Suppl C:S3-14.

6. Braman SS. The global burden of asthma. Chest 2006;130:4S-12S.

7. Pawankar R, Bunnag C, Khaltaev N, Bousquet J. Allergic rhinitis and its impact on asthma in Asia Pacific and the ARIA update 2008. World Allergy Organ J 2012;5:S212-7.

8. Song WJ, Kang MG, Chang YS, Cho SH. Epidemiology of adult asthma in Asia: Toward a better understanding. Asia Pac Allergy 2014;4:75-85.

9. Jindal SK, Aggarwal AN, Gupta D, Agarwal R, Kumar R, Kaur T, et al. Indian study on epidemiology of asthma, respiratory symptoms and chronic bronchitis in adults (INSEARCH). Int J Tuberc Lung Dis 2012;16:1270-7.

10. Scannapieco FA, Stewart EM, Mylotte JM. Colonization of dental plaque by respiratory pathogens in medical intensive care patients. Crit Care Med 1992;20:740-5.

11. Fourrier F, Duvivier B, Boutigny H, Roussel-Delvallez M, Chopin C. Colonization of dental plaque: A source of nosocomial infections in Intensive Care Unit patients. Crit Care Med 1998;26:301-8.

12. Kiyak HA, Grayston MN, Crinean CL. Oral health problems and needs of nursing home residents. Community Dent Oral Epidemiol 1993;21:49-52.

13. Karuza J, Miller WA, Lieberman D, Ledenyi L, Thines T. Oral status and resident well-being in a skilled nursing facility population. Gerontologist 1992;32:104-12.

14. Komiyama K, Tynan JJ, Habbick BF, Duncan DE, Liepert DJ Pseudomonas aeruginosa in the oral cavity and sputum of patients with cystic fibrosis. Oral Surg Oral Med Oral Pathol 1985;59:590-4.

15. Donowitz GR, Mandell GL. Acute pneumonia. In: Mandell GL, Doughlas RG, Benett JE, editors. Principles and Practise of Infectious Disease. New York: Churchill Livingstone; 1990. p. 540-55.

16. Finegold SM. Aspiration pneumonia. Rev Infect Dis 1991;13 Suppl 9:S737-42.

17. Schreiner A. Anaerobic pulmonary infections. Scand J Infect Dis Suppl 1979;(19):77-9.

18. Levison ME. Pneumonia, including necrotizing pulmonary infections (lung abscess). In: Isselbacher KJ, Braunwald E, Wilson JD, Martin JB, Fauci AS, Kasper DL, editors. Harrison's Principles of Internal Medicine. New York: McGraw-Hill; 1994. p. 1184-91.

19. Brook I, Frazier EH. Aerobic and anaerobic microbiology of empyema. A retrospective review in two military hospitals. Chest 1993;103:1502-7.

20. Goldstein EJ, Kirby BD, Finegold SM. Isolation of Eikenella corrodens from pulmonary infections. Am Rev Respir Dis 1979;119:55-8.

21. Morris JF, Sewell DL. Necrotizing pneumonia caused by mixed infection with Actinobacillus actinomycetemcomitans and Actinomyces israelii: Case report and review. Clin Infect Dis 1994;18:450-2.

22. Torres A, Dorca J, Zalacaín R, Bello S, El-Ebiary M, Molinos L, et al. Community-acquired pneumonia in chronic obstructive pulmonary disease: A Spanish multicenter study. Am J Respir Crit Care Med 1996;154:1456-61.

23. Grollier G, Doré P, Robert R, Ingrand P, Gréjon C, Fauchere JL, et al. Antibody response to Prevotella $\mathrm{spp}$. in patients with ventilator-associated pneumonia. Clin Diagn Lab Immunol 1996;3:61-5.

24. Langmore SE, Terpenning MS, Schork A, Chen Y, Murray JT, Lopatin D, et al. Predictors of aspiration pneumonia: How important is dysphagia? Dysphagia 1998; 13:69-81.

25. Johanson WG Jr., Higuchi JH, Chaudhuri TR, Woods DE. Bacterial adherence to epithelial cells in bacillary colonization of the respiratory tract. Am Rev Respir Dis 1980;121:55-63. 
Gupta, et al.: Association between periodontitis and respiratory disease

26. Woods DE, Straus DC, Johanson WG Jr., Bass JA. Role of fibronectin in the prevention of adherence of Pseudomonas aeruginosa to buccal cells. J Infect Dis 1981;143:784-90.

27. Gibbons RJ, Etherden I. Fibronectin-degrading enzymes in saliva and their relation to oral cleanliness. J Periodontal Res 1986;21:386-95.

28. Nakamura M, Slots J. Salivary enzymes. Origin and relationship to periodontal disease. J Periodontal Res 1983;18:559-69.

29. Loesche WJ, Syed SA, Stoll J. Trypsin-like activity in subgingival plaque. A diagnostic marker for spirochetes and periodontal disease? J Periodontol 1987;58:266-73.

30. Reddy MS, Murphy TF, Faden HS, Bernstein JM. Middle ear mucin glycoprotein: Purification and interaction with nontypable Haemophilus influenzae and Moraxella catarrhalis. Otolaryngol Head Neck Surg 1997; 116:175-80.

31. Scannapieco FA. Saliva-bacterium interactions in oral microbial ecology. Crit Rev Oral Biol Med 1994;5:203-48.

32. Reddi K, Wilson M, Nair S, Poole S, Henderson B. Comparison of the pro-inflammatory cytokine-stimulating activity of the surface-associated proteins of periodontopathic bacteria. J Periodontal Res 1996;31:120-30.

33. Wilson M, Reddi K, Henderson B. Cytokine-inducing components of periodontopathogenic bacteria. J Periodontal Res 1996;31:393-407.

34. Svanborg C, Hedlund M, Connell H,Agace W, Duan RD, Nilsson A, Wullt B. Bacterial adherence and mucosal cytokine responses. Receptors and transmembrane signalling. Ann NY Acad Sci 1996;797:177-90.

35. Khair OA, Davies RJ, Devalia JL. Bacterial-induced release of inflammatory mediators by bronchial epithelial cells. Eur Respir J 1996;9:1913-22.

36. Chawla R. Epidemiology, etiology, and diagnosis of hospital-acquired pneumonia and ventilator-associated pneumonia in Asian countries. Am J Infect Control 2008;36:S93-100.

37. Suwanagool S, Rothkopf MM, Smith SM, LeBlanc D, Eng R. Pathogenicity of Eikenella corrodens in humans. Arch Intern Med 1983;143:2265-8.

38. Zijlstra EE, Swart GR, Godfroy FJ, Degener JE. Pericarditis, pneumonia and brain abscess due to a combined Actinomyces - Actinobacillus actinomycetemcomitans infection. J Infect 1992;25:83-7.

39. Fourrier F, Cau-Pottier E, Boutigny H, Roussel-Delvallez M, Jourdain M, Chopin $\mathrm{C}$, et al. Effects of dental plaque antiseptic decontamination on bacterial colonization and nosocomial infections in critically ill patients. Intensive Care Med 2000;26:1239-47.

40. Genuit T, Bochicchio G, Napolitano LM, McCarter RJ, Roghman MC. Prophylactic chlorhexidine oral rinse decreases ventilator-associated pneumonia in surgical ICU patients. Surg Infect (Larchmt) 2001;2:5-18.

41. Adachi M, Ishihara K, Abe S, Okuda K, Ishikawa T. Effect of professional oral health care on the elderly living in nursing homes. Oral Surg Oral Med Oral Pathol Oral Radiol Endod 2002;94:191-5.

42. Koeman M, van der Ven AJ, Hak E, Joore HC, Kaasjager K, de Smet AG, et al. Oral decontamination with chlorhexidine reduces the incidence of ventilator-associated pneumonia. Am J Respir Crit Care Med 2006;173:1348-55

43. Awano S, Ansai T, Takata Y, Soh I, Akifusa S, Hamasaki T, et al. Oral health and mortality risk from pneumonia in the elderly. J Dent Res 2008;87:334-9.

44. Ishikawa A, Yoneyama T, Hirota K, Miyake Y, Miyatake K. Professional oral health care reduces the number of oropharyngeal bacteria. J Dent Res 2008;87:594-8.

45. Munro CL, Grap MJ, Jones DJ, McClish DK, Sessler CN. Chlorhexidine, tooth brushing, and preventing ventilator-associated pneumonia in critically ill adults. Am J Crit Care 2009;18:428-37.

46. Inuma T, Arai Y, Abe Y, Takayama M, Fukumoto M, Fukui Y, et al. Denture wearing during sleep doubles the risk of pneumonia in the very elderly. J Dent Res 2015;94:28S-36.

47. Juthani-Mehta M, Van Ness PH, McGloin J, Argraves S, Chen S, Charpentier $\mathrm{P}$, et al. A cluster-randomized controlled trial of a multicomponent intervention protocol for pneumonia prevention among nursing home elders. Clin Infect Dis 2015;60:849-57.

48. Jones PW, Harding G, Berry P, Wiklund I, Chen WH, Kline Leidy N, et al. Development and first validation of the COPD assessment test. Eur Respir J 2009;34:648-54.

49. Wedzicha JA, Bestall JC, Garrod R, Garnham R, Paul EA, Jones PW, et al. Randomized controlled trial of pulmonary rehabilitation in severe chronic obstructive pulmonary disease patients, stratified with the MRC dyspnoea scale. Eur Respir J 1998;12:363-9.

50. Prasanna SJ. Causal relationship between periodontitis and chronic obstructive pulmonary disease. J Indian Soc Periodontol 2011;15:359-65.

51. Scannapieco FA, Papandonatos GD, Dunford RG. Associations between oral conditions and respiratory disease in a national sample survey population. Ann Periodontol 1998;3:251-6.

52. Si Y, Fan H, Song Y, Zhou X, Zhang J, Wang Z, et al. Association between periodontitis and chronic obstructive pulmonary disease in a Chinese population. J Periodontol 2012;83:1288-96.

53. Kucukcoskun M, Baser U, Oztekin G, Kiyan E, Yalcin F. Initial periodontal treatment for prevention of chronic obstructive pulmonary disease exacerbations. J Periodontol 2013;84:863-70.

54. Zhou X, Han J, Liu Z, Song Y, Wang Z, Sun Z, et al. Effects of periodontal treatment on lung function and exacerbation frequency in patients with chronic obstructive pulmonary disease and chronic periodontitis: A 2-year pilot randomized controlled trial. J Clin Periodontol 2014;41:564-72.

55. Nisengard R. Immediate hypersensitivity and periodontal disease. J Periodontol 1974;45:344-7.

56. Nisengard RJ. The role of immunology in periodontal disease. J Periodontol 1977;48:505-16.

57. Hyyppä TM, Koivikko A, Paunio KU. Studies on periodontal conditions in asthmatic children. Acta Odontol Scand 1979;37:15-20.

58. Shulman JD, Nunn ME, Taylor SE, Rivera-Hidalgo F. The prevalence of periodontal-related changes in adolescents with asthma: Results of the Third Annual National Health and Nutrition Examination Survey. Pediatr Dent 2003;25:279-84.

59. Friedrich N, Völzke H, Schwahn C, Kramer A, Jünger M, Schäfer T, et al. Inverse association between periodontitis and respiratory allergies. Clin Exp Allergy 2006;36:495-502.

60. Yaghobee S, Paknejad M, Khorsand A. Association between asthma and periodontal disease. J Dent Tehran Univ Med Sci 2008;5:47-51.

61. Gomes-Filho IS, Soledade-Marques KR, Seixas da Cruz S, de Santana Passos-Soares J, Trindade SC, Souza-Machado A, et al. Does periodontal infection have an effect on severe asthma in adults? J Periodontol 2014;85:e179-87.

62. Rivera R, Andriankaja OM, Perez CM, Joshipura K. Relationship between periodontal disease and asthma among overweight/obese adults. J Clin Periodontol 2016;43:566-71.

63. Hayes C, Sparrow D, Cohen M, Vokonas PS, Garcia RI. The association between alveolar bone loss and pulmonary function: The VA dental longitudinal study. Ann Periodontol 1998;3:257-61.

64. Scannapieco FA, Ho AW. Potential associations between chronic respiratory disease and periodontal disease: Analysis of national health and nutrition examination survey III. J Periodontol 2001;72:50-6.

65. Hyman JJ, Reid BC. Cigarette smoking, periodontal disease: And chronic obstructive pulmonary disease. J Periodontol 2004;75:9-15.

66. Kowalski M, Kowalska E, Split M, Split W, Wierzbicka-Ferszt A, Pawlicki L, et al. Assessment of periodontal state in patients with chronic obstructive pulmonary disease - Part II. Pol Merkur Lekarski $2005 ; 19: 537-41$

67. Katancik JA, Kritchevsky S, Weyant RJ, Corby P, Bretz W, Crapo RO, et al. Periodontitis and airway obstruction. J Periodontol 2005;76:2161-7.

68. Leuckfeld I, Obregon-Whittle MV, Lund MB, Geiran O, Bjørtuft Ø, Olsen I, et al. Severe chronic obstructive pulmonary disease: Association with marginal bone loss in periodontitis. Respir Med 2008;102:488-94.

69. Deo V, Bhongade ML, Ansari S, Chavan RS. Periodontitis as a potential risk factor for chronic obstructive pulmonary disease: A retrospective study. Indian J Dent Res 2009;20:466-70.

70. Lee SW, Lim HJ, Lee E. Association between asthma and periodontitis: Results from the Korean national health and nutrition examination survey. J Periodontol 2017;88:575-81.

71. Shen TC, Chang PY, Lin CL, Wei CC, Tu CY, Hsia TC, et al. Risk of periodontal disease in patients with asthma: A nationwide population-based retrospective cohort study. J Periodontol 2017;88:723-30.

72. Soledade-Marques KR, Gomes-Filho IS, da Cruz SS, Passos-Soares JS, 
Gupta, et al:: Association between periodontitis and respiratory disease

Trindade SC, Cerqueira EM, et al. Association between periodontitis and severe asthma in adults: A case-control study. Oral Dis 2018;24:442-8.

73. Moraschini V, Calasans-Maia JA, Calasans-Maia MD. Association between asthma and periodontal disease: A systematic review and meta-analysis. J Periodontol 2018;89:440-55.

74. Avdonina LI, Gedymin LE, Erokhin VV. Tuberculous periodontitis. Probl Tuberk 1993;(4):4-7.

75. Anjum S, Reddy PP, Monica M, Praveen BH. Oral health status of the patients with tuberculosis at the Govt TB and chest diseases hospital, Andhra Pradesh, India. Int J Dent Clin 2010;2:12-5.

76. Palakuru SK, Lakshman VK, Bhat KG. Microbiological analysis of oral samples for detection of mycobacterium tuberculosis by nested polymerase chain reaction in tuberculosis patients with periodontitis. Dent Res J (Isfahan) 2012;9:688-93.
77. Sharma A, Garg H, Khattri S, Sharma S. Periodontal status of tuberculosis patients - Is there a two-way link? Indian J Tuberc 2016;63:225-9.

78. Santos SR, Pinto EH, Longo PL, Corso SD, Lanza FC, Stelmach R, et al. Effects of periodontal treatment on exacerbation frequency and lung function in patients with chronic periodontitis: Study protocol of a 1-year randomized controlled trial. BMC Pulm Med 2017;17:23.

79. Pinto EH, Longo PL, de Camargo CC, Dal Corso S, Lanza Fde C, Stelmach R, et al. Assessment of the quantity of microorganisms associated with bronchiectasis in saliva, sputum and nasal lavage after periodontal treatment: A study protocol of a randomised controlled trial. BMJ Open 2016;6:e010564.

80. Laurikainen K, Kuusisto P. Comparison of the oral health status and salivary flow rate of asthmatic patients with those of nonasthmatic adults-results of a pilot study. Allergy 1998;53:316-9. 